\title{
A Study on Mixing Camel Milk with Cow, Sheep and Goat Milk in Different Proportions in Yoghurt Production
}

\author{
Selda Bulca ${ }^{1, a, *}$, Bengisu Dumanoğlu ${ }^{1, b}$, Ömer Cem Özdemir ${ }^{1, c}$ \\ ${ }^{l}$ Department of Food Engineering, Faculty of Engineering, Aydin Adnan Menderes University, 09100 Efeler/Aydin, Turkey
} *Corresponding author

\section{A R T I C LE IN F O}

Research Article

Received : 11/07/2019

Accepted : 15/11/2019

Camel milk

Viscosity

Syneresis

Water holding capacity

\section{Keywords:}

Yoghurt production

\begin{abstract}
A B S T R A C T
Recently, the use of camel milk has increased as a new and alternative animal protein source for human consumption. However, there are some differences in the composition of camel milk compared with other kind of milk sources. One of these differences is that camel milk contains in high concentrations of antimicrobial agents such as lysozyme, lactoferrin, lactoperoxidase and immunoglobulins. In many studies, it was reported that camel milk is not suitable for production of fermented milk especially for yoghurt due to the high concentration of antimicrobial substances. The aim of this study, to investigate suitability of the mixture of camel milk with different ratio of cow, sheep and goat milk for yoghurt production. After preparing of milk mixtures heat treated at $90^{\circ} \mathrm{C}$ for 15 minutes the mixtures were cooled to $45^{\circ} \mathrm{C}$. The starter culture (YC 350) was added and incubated at $42^{\circ} \mathrm{C}$ until the $\mathrm{pH}$ reached 4.7. During fermentation every hour the $\mathrm{pH}, \mathrm{SH}$ and viscosity were measured. According to the results of analysis in which the highest viscosity and the fastest $\mathrm{pH}$ drop, mixtures were chosen as optimum points for yoghurt production. In these optimum points yoghurt production were performed and all of the samples were stored for 1., 7., 14. and 28. days at $4^{\circ} \mathrm{C}$. During the storage, water holding capacity and syneresis analyses were conducted. According to the results, the optimum mixture was determined at $80 \%: 20 \%$ cow milk:camel milk mixture. However, after 4 weeks of storage it was concluded that an increase in the syneresis and a decrease in water holding capacity (\%) were found for yoghurt obtained from $80 \%: 20: \%$ cow-camel milk mixture.
\end{abstract}

Türk Tarım - Gıda Bilim ve Teknoloji Dergisi 7(12): 2095-2102, 2019

\section{Yoğurt Üretiminde Deve Sütünün Farklı Oranlarda Sığır, Koyun, Keçi Sütleriyle Karışımının Kullanımı Üzerine Bir Araştırma}

Deve sütü, son zamanlarda insan tüketimi için yeni ve alternatif bir hayvansal protein kaynağı haline gelmiştir. Ancak, deve sütünün bileşimi diğer süt çeşitleriyle karşılaştırıldığında bazı farklılıklar göstermektedir. Bu farklılıklardan birisi, deve sütünün lizozim, laktoferrin, laktoperoksidaz ve immünoglobulinler gibi yüksek konsantrasyonlarda antimikrobiyal maddeler içermesidir. Çoğu çalışmada deve sütünün yüksek oranda antimikrobiyal maddeler içermesinden dolayı fermente süt ürünleri özellikle de yoğurt üretimi için uygun olmadığı rapor edilmiştir. Bu çalışmanın amacı, deve sütünün farklı oranda sığır, keçi ve koyun sütü ile karıştırılarak yoğurt üretimine uygunluğunun araştırılmasıdır. Belirlenen oranlarda karışımlar hazırlandıktan sonra, miksler $90^{\circ} \mathrm{C}$ 'de 15 dakika ısıl işleme tabi tutulmuş ve $45^{\circ} \mathrm{C}^{\prime}$ ye soğutulmuştur. Starter (YC-350) ilave edildikten sonra pH 4,7'ye ulaşıncaya kadar $42^{\circ} \mathrm{C}$ 'de inkübe edilmiştir. Fermantasyon sırasında her saat $\mathrm{pH}$, SH ve viskozite ölçümleri gerçekleştirilmiştir. Analiz sonuçlarına göre yoğurt üretimi için $\mathrm{pH}$ düşüşünün en hızlı ve viskozitenin en yüksek olduğu optimum noktaları gösteren süt karışımları seçilmiştir. Bu optimum noktalarda yoğurt üretimi yapılarak 1., 7., 14. ve 28 . gün boyunca $4^{\circ} \mathrm{C}^{\prime}$ de depolanmıştır. Depolama boyunca su tutma kapasitesi ve sinerez analizleri yapılmıştır. Analiz sonuçlarına göre en optimum karışımın \%80:\%20 ineksütü: deve sütü karışımı olduğu belirlenmiştir. Ancak, 4 haftalık depolamadan sonra, 80\%:20\% inek sütü-deve süt karışımından elde edilen yoğurtta sinerezde bir artış ve su tutma kapasitesinde bir düşüş (\%) olduğu sonucuna varılmıştır. 


\section{Introduction}

Yoghurt is one of the important fermented dairy product produced by adding starter cultures such as Lactobacillus delbrueckii subsp. bulgaricus and Streptococcus thermophilus. Starter cultures used in the production of fermented milk products due to the rapid growing in the milk (Shirai, 2001). Nowadays, yoghurt is produced from cow milk, followed from sheep milk and goat milk.

Aydin is an important region for camel wrestling and therefore is getting more and more popularity not only for camel wrestling but also for camel farming. The increase of camel farming and camel wrestling in this region made it possible the production of the camel milk as an alternative milk source. Camel milk, which is consumed and processed more in African countries, has a great importance in the world because of its benefits to human health as a consequence of researches.

Camels usually prefer to eat high-salt crops, so their milk may be sweet, salty or bitter (Yagil, 1982). The titratable acidity of camel milk is higher than human milk and lower than cow milk, sheep and goat milk. Fat and protein content of single-humped camel milk is similar to cow milk, but protein and fat concentration are lower than that of sheep milk and double-humped camel milk. Double humped camel milk has higher amount of caseins and whey proteins than other mammalian milk, including sheep milk (Semen and Altıntaş, 2016). In Table 1, the physical and chemical properties of different kind of milks are showed.

One of the most important features of camel milk compared to cow or sheep milk is that it does not contain $\beta$-Lactoglobulin that has allergic properties. Elagamy et al., (2009) found that the electrophoretic patterns of camel milk revealed $\beta$-lactoglobulin is present in cow milk but absent in both camel and human milk. Kappeler (1998) concluded that also camel milk is free of $\beta-\lg$ which is konown one of the major antigens of cow milk proteins.

Cow milk allergy is the sensitivity of our body's immune system against proteins in milk. Studies have reported that $12.6 \%$ of the total food-related allergies in children younger than 15 months constitute milk allergies. These allergies are known as cow milk allergy and are seen in $1 \%$ of babies who is fed with breast milk and $0.1 \%$ of adults. The frequency of such allergies in the general population is between $0.3 \%$ and $7.5 \%$ and in children is between $22.9 \%$ and $24.0 \%$. Among some children, these allergic conditions persist throughout their lives. The incidence of milk allergy was found to be $0.3-0.75 \%$ in children in different countries (Dean, 1995; Motrichet al., 2003).

Camel milk colostrum contains more serum proteins than normal milk, mainly immunoglobulin G (IgG), which protects the immune system of the newborn (El Agamy et al., 1996)

Camel milk is used as cure material for treatment of different kinds of diseases such as hypertension, jaundice, tuberculosis, asthma. In addition, camel milk have developed long-term glycemic control and have been reported to reduce insulin dose in type 1 diabetes patients (Mudgil et al., 2018; Ayyash et al., 2018). It is also used in the strengthening of the immune system, reducing the risk of cancer, reducing the growth of cancer cells (Ayyash et al., 2018, Al-Fakharany et al., 2018), lowering cholesterol levels (Kaskous, 2016).It has been estimated that camel milk has also antioxidant properties (Ayyash et al., 2018) and provides improvement in autistic children carrying autism spectrum syndrome (Al-Ayadhi and Elamin, 2013). In some studies it was concluded that camel milk possessed antimicrobial (Kumar et al., 2016; Abusheliabi et al., 2017), antiobesity (Mudgil et al., 2018) and antiviral properties (El-Agamy et al., 1992; Hara et al. 2002).

Many scientific researches were performed to investigate the chemical, physical properties and microbiological quality of camel milk. Moreover, the technological applications were limited to produce different kinds of milk products where the camel farm applied intensively. In some studies, it was found that the production of yoghurt from camel milk brings about some problems during fermentation. It occurs no coagulation in cultured camel milk (Konuspayeva et al., 2007; Benkerroum, 2008). It is claimed that camel milk contains at high concentrations of antimicrobial substances such as lyzozyme, lactoferrin, lactoperoxidase and immunoglobulins are heat stable and by heating they can't be inhibited and supress the growth of starter cultures in cultured milk. Therefore, camel milk is often mixed with fresh or other cultured species (cows, goats and sheep) particularly (Eyassu, 2008). As another way is used the addition of different kinds of hydrocolloids to produce yoghurt gel with good textural properties.

Table 1 Physicochemical properties of camel milk and other types of milk (Park et al, 2007).

\begin{tabular}{l|rrrrrr}
\hline \multicolumn{1}{c|}{ Components } & Camel $^{(1)}$ & Camel $^{(2)}$ & \multicolumn{1}{c}{ Cow } & Human & Sheep & Goat \\
\hline Water \% & 87.58 & 84.80 & 87.77 & 88.66 & 82.95 & 87.30 \\
Dry Matter \% & 12.41 & 15.19 & 12.25 & 11.34 & 17.05 & 12.12 \\
Fat \% & 3.96 & 5.32 & 3.60 & 2.80 & 5.95 & 4.15 \\
Protein \% & 3.22 & 4.09 & 3.24 & 1.91 & 5.25 & 3.02 \\
Casein \% & 2.40 & 3.01 & 2.51 & 0.71 & 4.06 & 2.32 \\
Whey Protein \% & 0.93 & 1.02 & 0.73 & 1.26 & 1.19 & 0.70 \\
Lactose & 4.56 & 4.95 & 4.65 & 6.30 & 4.91 & 4.21 \\
Ash \% & 0.79 & 0.81 & 0.76 & 0.27 & 0.94 & 0.74 \\
pH & 6.55 & - & 6.68 & 6.90 & 6.79 & 6.70 \\
Acidity \% & 1.15 & - & 0.18 & 0.06 & 0.19 & 0.17 \\
\hline
\end{tabular}

Camel (1): single humped camel; Camel (2): double humped camel 
When it is considered the literature data, it can be concluded that there are not enough studies about camel milk yoghurt. The available works are explained below.

In the study of Eissa et al. (2011) the physicochemical, microbiological and sensory characteristics of yoghurt produced from camel milk during storage were performed. It was investigated that physicochemical, microbiological and sensory attributes before and after storage (5, 10 and 15 days) of yoghurt produced from camel milk. It was shown that cow milk yoghurt was found to be more viscous than camel milk yoghurt. Storage resulted in significant changes in gross composition of both yoghurt types. Organoleptic tests revealed that camel yoghurt had significantly lower quality from consumers than cow milk yoghurt.

Jumah et al. (2001) used different kinds of milks (ovine, caprine, bovine and camel milks) to compare the rheological properties of yoghurt during the gelation process. It was concluded that bovine, ovine and caprine milk showed similar viscosity incubation time, whereas camel milk showed no remarkable variations in viscosity during incubation.

In some studies the effect of the addition different kind of stabilizers such as carrageenan, carboxylmetthylcellulose, pectin, gum acacia, alginate to camel milk was investigated to improve the yoghurt gel formation. The following results were found.

Al-Zoreky et al. (2015) used for the improvement of the camel milk yoghurt structure different kinds of hydrocolloids such as carboxylmethylcellulose, pectin, gum acacia, or alginate with different concentrations. They found that the syneresis of camel milk yoghurt with alginate addition was higher than for control cow milk yoghurt and water holding capacity was weaker. It was also observed that stabilizers did not improve the consistency and coagulum of camel milk yoghurt compared with bovine milk yoghurt.

A similar study was performed by Hashim et al., (2009) to determine the quality and acceptability of a set-type yoghurt made from camel milk. In order to increase the viscosity of yoghurt they used gelatin, alginate and calcium. Although the sensory analysis of yoghurt samples of camel yoghurt were better with the addition of $0.75 \%$ sodium alginate $+0.075 \%$ calcium chloride, the rheological properties of yoghurt in this study were not measured.

Except from the use of the addition of stabilizers explained above an alternative method was to produce stable yoghurt with high consistency and good textural properties by mixing of camel milk with different kinds of milks (cow, sheep, goat exc.). The related recent studies given below.

Shimaa and Ibtisam (2016) investigated to improve the processing properties of yoghurt made from camel:sheep milk mixtures with different proportions and at the same time the suitability of two starter cultures were tried out. Products were evaluated in terms of chemical composition and consistency. It was concluded that an addition of sheep milk to that of camel improved the quality and acceptability of camel milk yoghurt.

In another study was performed by Elniema and Tabiti (2015). Its aim was to determine the possibility of manufacturing yoghurt by mixing different percentages of cow milk to camel milk and to detect the effect of cow milk on the physiochemical and sensory characteristics of camel milk yoghurt. It was found that camel milk got lower physiochemical and sensory quality compared to cow milk, so mixing high percentages of cow milk $(75 \%)$ to camel milk $(25 \%)$ in yoghurt production, improved physiochemical properties and sensory evaluation of camel's milk yoghurt.

In the study of El-Zubeir et al. (2012) goat milk and sheep milk was used to produce yoghurt but not as mixture. Following and during the production the chemical characteristics, sensory properties were evaluated. It was concluded that the longer incubation period of yoghurt prepared from camel milk supported the previous work of Hassan et al. (2006). This might be due to that camel milk contains antibacterial agent (Elagamy et al., 1992).

Cow milk generally contains large amounts of basic components such as protein, fat, sugar. It also contains a small amount of enzymes, vitamins and minerals. The fat content of cow milk is between $2.5-6.0 \%$, the dry matter is $10.5-14.5 \%$, the lactose content is $3.6-5.5 \%$, the protein ratio is $2.9-5.0 \%$ and the mineral content is $0.6-0.9 \% .80 \%$ of the milk proteins makes up casein and $20 \%$ of the serum proteins. Caseins are phosphorus compounds which consist of four different subfraction called $\alpha \mathrm{s} 1-, \alpha s 2-, \beta-$, and $\mathrm{K}-$ casein and contain soluble, colloidal calcium. Depending on the composition, the acidity is between 6.2 and $8.9 \mathrm{SH}$ and the density ranges from 1.028 to $1.039 \mathrm{~g} / \mathrm{ml}$ (Gürsoy, 2015). Most of the milk fat consists of complex triglycerides and the other part consists of phospholipids, cholesterol, free fatty acids, mono and diglyceride lipid components. In addition, it contains many minor proteins and enzymes.

Sheep milk has a higher nutritional value of protein, fat and mineral concentration than camel, goat and cow milk. The dry matter content is $50 \%$ higher than cow milk. Natural acidity is higher and titration acidity is generally between 8-12 SH. In addition, the density of sheep milk is 1.030-1.045 g/ml (Gürsoy, 2015). Sheep milk is rich in casein (4.2 to $5.2 \mathrm{~g} / 100 \mathrm{~g}$ ) and whey proteins (1.02 to 1.3 g/100 g); (Dario et al., 2008; Selvaggi et al.,2014).

Goat milk shows similarity to cowmilk in terms of its composition. It is claimed that goat milk is more valuable than cow milk due to the differences in some of its physicochemical properties. Generally the acidity is 6.4-10 $\mathrm{SH}$, the density is in the range of $1.028-1.041 \mathrm{~g} / \mathrm{ml}$ (Gürsoy, 2015). Fresh goat milk contains a higher proportion of fat globules of smaller diameter than cow milk and is more easily digested. Goat milk includes more chloride and potassium than cow milk, but it contains less, $\mathrm{N}$-acetyl neuraminic acid, folate, orotic acid, vitamin B6, and vitamin $\mathrm{B}_{12}$ (Jenness, 1980).

In many studies it was concluded that pure camel milk does not coagulate and if coagulates needs longer time for coagulation. According to some authors this problem is related with the high concentration of antimicrobial substances which supress the growth of starter bacteria (Jans et al., 2012; Bornaz et al., 2009). The cultured milk becomes a watery consistency with fragile and poor structure (Abdel Rahman et al. 2009). According to other authors the undesirable structure of cultured camel milk formation is attributed to the differences in the size and properties of casein particles (Farah and Atkins, 1992). It is also claimed that camel milk contains larger casein micelles than bovine milk coagulum (Farah and Rüegg, 1989). 
Because of unsuitability of pure camel milk due to above mentioned factors for the yoghurt production the first aim of this study was to investigate the the possibility of manufacturing yoghurt by mixing different percentages with cow, sheep and goat milk to camel milk and to detect their suitability for yoghurt production. Therefore, in this work it was focussed not only on the coagulation process but also to determine some properties during storage periode for 4 weeks.

\section{Materials and Methods}

\section{Materials}

Raw camel milk is obtained from a camel farm in Incirliova/Aydın, cow milk is obtained from local market and raw sheep milk is obtained from Faculty for Agriculture, Aydın Adnan Menderes University. Raw goat milk was supplied from a dairy industry located in Koçarl /Aydin.

In this study, YC-350 starter culture which contains Lactobacillus delbrueckii subsp. bulgaricus and Streptococcus thermophilus was used for production of yoghurt. YC-350 starter culture was obtained from Chr. Hansen'sLaboratorium Denmark A/S, Izmir.

\section{Yoghurt Production}

Milk samples were supplied and filled in clean plastic bottles. After heating the milk samples at $45^{\circ} \mathrm{C}$ in the water bath, the fat separation was performed. By means of milk separator the milk was circulated 3 times to reduce the fat content of milk. After that the separation of the fat content in cream and skimmed milk were analysed. After mixing of each combination of milk samples were stored in freezer in plastic bottles.

Frozen milk in plastic bottles were taken out from the deep freezer and dissolved in water bath. Camel milk was mixed with cow milk, sheep milk and goat milk according to ratios given in the table below. After mixing of milk mixtures heat treated at $90^{\circ} \mathrm{C}$ for 15 minutes the mixtures were cooled to $45^{\circ} \mathrm{C}$. The starter culture was added and incubated at $42^{\circ} \mathrm{C}$ until the $\mathrm{pH}$ reached 4.7 and all of the samples were storaged for 1., 7., 14. and 28 . days at $4{ }^{\circ} \mathrm{C}$.

\section{Determination of Dry Matter Content of Milk}

Determination of dry matter in milk and milk samples to be used was determined using gravimetric method according to TS 1018 Raw Milk Standard.

\section{Determination of Ash Content of Milk}

The amount of ash of milk samples were determined using the gravimetric method (Kurt et al., 1993).

\section{Determination of Nitrogen Content of Milk}

The amount of nitrogen in the camel milk and other milks was determined according to the Kjeldahl method and the values to be obtained multiplied by the factor of 6.38 and the amounts of protein will be determined (Kurt et al. 1993).

\section{Determination of Fat Content of Milk}

The fat contents of the milk samples were determined by Gerber method using butyrometer. $10 \mathrm{ml}$ sulphuric acid (90-91\%) than $11 \mathrm{ml}$ milk and $1 \mathrm{ml}$ amyl alcohol were added into milk butyrometer. The butyrometer was shaken slowly. After that butyrometers were placed in a Gerber centrifuge (Funke Gerber, Nova Safety) and centrifugated at $65^{\circ} \mathrm{C}$ for 5 minutes. After that the fat content of milk was read from the green coloured scale.

Determination of pH of Milk and Yoghurt Samples

The $\mathrm{pH}$ meter (Mettler Toledo seven2go, Germany) was used to measure of $\mathrm{pH}$ of samples. Before measuring of $\mathrm{pH}$ of samples, $\mathrm{pH}$ meter was calibrated with buffer solutions with different $\mathrm{pH}$ values $(\mathrm{pH} 4$ and 9). After calibration the $\mathrm{pH}$ meter was put in to the milk or yoghurt samples and waited for a pair minute to get the $\mathrm{pH}$ of samples.

Determination of Soxhelet-Henkel Value of Milk and Yoghurt Samples

The determination of titratable acidity of yoghurt and milk samples was determined by Soxhelet-Henkel method in TS 1018 Raw Milk Standard. $25 \mathrm{ml}$ of sample was pipetted in volumetric flask. Two drops of phenolophthalein were added. Sample was titrated with $0.25 \mathrm{~N} \mathrm{NaOH}$ until light pink colour obtained. After the addition of $1.2 \mathrm{~g} / \mathrm{L}$ starter culture to the camel milk, the changes in viscosity was measured with FungilabExpert V301002 during the fermentation every 60 minutes until the milk pH reached 4.6.

\section{Storage Analysis of Yoghurt}

After production of yoghurt samples which were prepared according to Figure 1, the samples were stored for 1., 7., 14. and 28. days in order to determine the syneresis and water holding capacity.

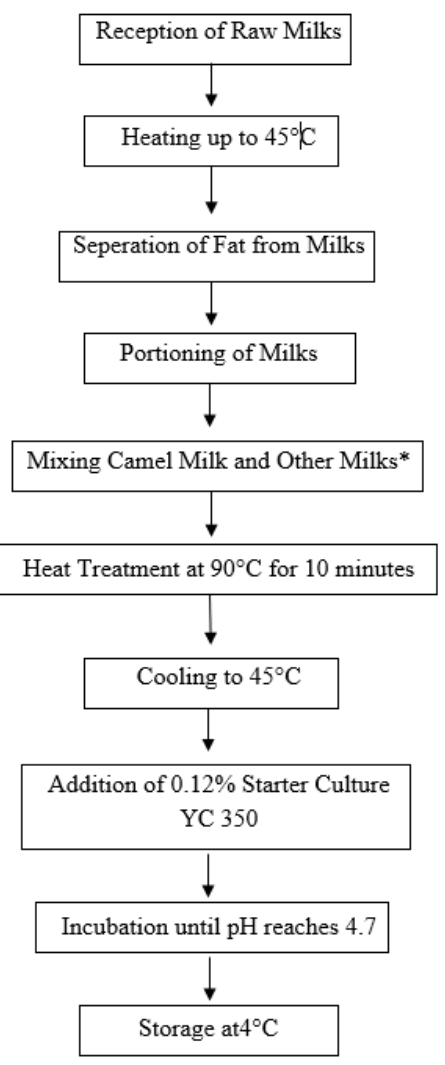

Figure 1 Yoghurt production scheme 


\section{Determination of Syneresis of Yoghurt}

25 grams of yoghurt was weighed and passed through filter paper No. 615 and filtered. In this way, the weight of the serum phase passed down was measured. Drainage was applied at $4^{\circ} \mathrm{C}$ for 120 minutes (Tamime et al., 1996; Sahan et al., 2008).

Determination of Water Bonding Capacity of Yoghurt

20 grams of yoghurt samples that found in the falkon tubes were centrifuged at $1800 \mathrm{~g}$ for 30 minutes. After centrifuging at $10^{\circ} \mathrm{C}$ for 30 minutes, pellet and serum phase were weighed and water retention capacity was calculated according to the formula below.

$$
\mathrm{WHC}=1-\frac{\mathrm{Wt}}{\mathrm{Wi}} \times 100
$$

Where $W t$ is weight $(\mathrm{g})$ of the pellet and $W i$ is initial weight $(\mathrm{g})$ of the sample.

\section{Statistical Analyses}

Experiment were replicated twice. Data was generated and analysed by statistical analysis system program SigmaPlot version 12.0 using One Way ANOVA.

\section{Results and Discussions}

For the production of yoghurt from camel milk and goat, sheep and cow milk mixtures with different percentages were prepared. Protein, ash and dry matter analyses of camel-cow, camel:sheep, camel:goat milk mixtures were determined. The obtained results were shown in Table 2.

As seen in Table 2, the highest protein as well as dry matter contents were assessed in sheep:camel milk mixture. The higher the percentages of sheep and goat milk in the mixture, the higher was the protein and dry matter contents of the mixture. The dry matter content was lowest $(9.08 \%)$ in the mixture of $70 \%$ cow:30\% camel milk. This observation was also determined in the study of Elniema et al. (2015) who found that the higher the ratio of camel milk in the mixture the lower was the dry matter content of mixture.

After obtaining the preliminary experiments, optimum values were determined, in which the camel:other kind of milk combination selected according to the results of high viscosity and rapid $\mathrm{pH}$ drop in the mixture. These are; $80 \%$ cow milk $+20 \%$ camel milk; $70 \%$ cow milk $+30 \%$ camel milk; $80 \%$ sheep milk $+20 \%$ camel milk; $70 \%$ sheep +30 $\%$ camel milk; $80 \%$ goat milk $+20 \%$ camel milk and $70 \%$ goat $+30 \%$ camel'milk. A total of 6 different combinations were selected.

During yoghurt production, the time-dependent change of viscosity, $\mathrm{pH}$ and titratable acidity $(\mathrm{SH})$, which are three basic parameters in our study, were controlled until the $\mathrm{pH}$ reached the isoelectric point to $\mathrm{pH} 4.7$ during incubation. As seen in Table 3 the incubation time both in the 80\%:20\% cow:camel milk mixture and in 70\%:30\% cow:camel milk took 3 hours. The $\mathrm{pH}$ drop of $80 \%: 20 \%$ cow:camel milk mixture after 3 hours was faster than in the mixture of $70 \%: 30 \%$ cow:camel milk mixture. In terms of viscosity there was no significant effect in both mixtures. In both mixtures after 3 hours' fermentation time the viscosities were higher than in goat-camel and sheep-camel milk mixtures were determined.

According to the statistical evaluation in the $\mathrm{pH}$ of 80\%:20\% cow:camel milk mixture and 70\%:30\% mixture yoghurt samples during incubation significant differences were noted $(\mathrm{P}<0.05)$ but in $\mathrm{SH}$ and viscosity values of 80\%:20\% mixture and 70\%:30\% mixture yoghurt samples during incubation there were obtained no significant differences $(\mathrm{P}>0.05)$. However Elniema et al. (2015)'s work showed that the effect of different yoghurt samples from camel and cow milk yoghurt had no significant difference $(\mathrm{P} \geq 0.05)$ on $\mathrm{pH}$, but significantly affected the acidity of mixture of camel and cow milk yoghurt samples.

As shown in $\mathrm{n}$ Table 4, $\mathrm{pH}, \mathrm{SH}$ and viscosity parameters were analysed. As seen in table 4 the $80 \%: 20 \%$ goat:camel milk mixture and 70\%:30\% goat:camel milk mixture the $\mathrm{pH}$ drop, $\mathrm{SH}$ values were similar to each other. However, the viscosity of 70\%:30\% goat:camel milk mixture after $3.5 \mathrm{~h}$ incubation higher than 80\%:20\%goat:camel milk mixture.

Table 2 Protein, ash and dry matter content of the optimum values of mixture of camel milk with cow-goat-sheep milk

\begin{tabular}{l|ccc}
\hline $\begin{array}{c}\text { Ratio of camel milk to } \\
\text { other kinds of milk }\end{array}$ & Protein(\%) & Ash $(\%)$ & Dry Matter(\%) \\
\hline $80: 20$ cow-camel & $3.85 \pm 0.06$ & $0.97 \pm 0.02$ & $10.0 \pm 0.02$ \\
$70: 30$ cow-camel & $3.41 \pm 0.05$ & $0.80 \pm 0.04$ & $9.08 \pm 0.04$ \\
80:20 sheep-camel & $5.62 \pm 0.03$ & $0.96 \pm 0.05$ & $12.5 \pm 0.05$ \\
$70: 30$ sheep -camel & $5.43 \pm 0.04$ & $0.93 \pm 0.03$ & $11.83 \pm 0.07$ \\
80:20 goat-camel & $4.43 \pm 0.06$ & $0.73 \pm 0.05$ & $11.21 \pm 0.05$ \\
$70: 30$ goat-camel & $4.07 \pm 0.04$ & $0.63 \pm 0.03$ & $11.50 \pm 0.04$ \\
\hline
\end{tabular}

Table 3 The $\mathrm{pH}$, SH and viscosity values of the optimum mixtures of cow-camel milk

\begin{tabular}{c|cccccc}
\hline \multirow{2}{*}{$\begin{array}{c}\text { Time } \\
\text { (h) }\end{array}$} & \multicolumn{4}{|c}{$80: 20$} & \multicolumn{3}{c}{$70: 30$} \\
\cline { 2 - 7 } & $\mathrm{pH}$ & $\mathrm{SH}$ & Viscosity $(\mathrm{mPa} . \mathrm{s})$ & $\mathrm{pH}$ & $\mathrm{SH}$ & Viscosity $(\mathrm{mPa} . \mathrm{s})$ \\
\hline $0^{*}$ & $6.65^{\mathrm{a}, \mathrm{A}} \pm 0.0$ & $7.6^{\mathrm{a}, \mathrm{A}} \pm 0.0$ & $5127^{\mathrm{a}, \mathrm{A}} \pm 650.25$ & $6.565^{\mathrm{a}, \mathrm{B}} \pm 0.0$ & $7.6^{\mathrm{a}, \mathrm{A}} \pm 0.00$ & $4585^{\mathrm{a}, \mathrm{A}} \pm 94.7$ \\
1 & $5.82^{\mathrm{b}, \mathrm{A}} \pm 0.03$ & $15.2^{\mathrm{b}, \mathrm{A}} \pm 1.13$ & $5218.54^{\mathrm{a}, \mathrm{A}} \pm 203.95$ & $5.935^{\mathrm{b}, \mathrm{B}} \pm 0.0$ & $13.2^{\mathrm{b}, \mathrm{A}} \pm 0.56$ & $5032.44^{\mathrm{a}, \mathrm{A}} \pm 329.95$ \\
2 & $5.145^{\mathrm{c}, \mathrm{A}} \pm 0.05$ & $24.8^{\mathrm{c}, \mathrm{A}} \pm 0.05$ & $6701.43^{\mathrm{a}, \mathrm{A}} \pm 613.92$ & $5.24^{\mathrm{c}, \mathrm{B}} \pm 0.01$ & $24.6^{\mathrm{c}, \mathrm{A}} \pm 0.28$ & $6000.85^{\mathrm{a}, \mathrm{A}} \pm 985.71$ \\
3 & $4.74^{\mathrm{d}, \mathrm{A}} \pm 0.04$ & $30.2^{\mathrm{d}, \mathrm{A}} \pm 0.28$ & $11806.03^{\mathrm{a}, \mathrm{A}} \pm 734.84$ & $4.83^{\mathrm{d}, \mathrm{A}} \pm 0.06$ & $32.2^{\mathrm{d}, \mathrm{A}} \pm 0.28$ & $11969.27^{\mathrm{b}, \mathrm{A}} \pm 1604.51$ \\
\hline
\end{tabular}

*Different superscript letters (a to d) within the same column and (A to B) within same row showed significant differences among the groups ( $<<0.05$ ).

0 . $\mathrm{h}$ indicates the $\mathrm{pH}$ and $\mathrm{SH}$ level of milk at the beginning of the fermentation after the starter culture addition 
Table 4 The $\mathrm{pH}, \mathrm{SH}$ and viscosity values of the optimum mixtures of goat-camel milk

\begin{tabular}{c|cccccc}
\hline \multirow{2}{*}{$\begin{array}{c}\text { Time } \\
\text { (h) }\end{array}$} & \multicolumn{5}{|c}{$80: 20$} & \multicolumn{3}{c}{$70: 30$} \\
\cline { 2 - 7 } & $\mathrm{pH}$ & $\mathrm{SH}$ & Viscosity $(\mathrm{mPa} . \mathrm{s})$ & $\mathrm{pH}$ & $\mathrm{SH}$ & Viscosity $(\mathrm{mPa} . \mathrm{s})$ \\
\hline 0 & $6.415^{\mathrm{a}, \mathrm{A}} \pm 0.0$ & $9.6^{\mathrm{a}, \mathrm{A}} \pm 0.56$ & $1077^{\mathrm{a}, \mathrm{A}} \pm 31.68$ & $6.44^{\mathrm{a}, \mathrm{B}} \pm 0.0$ & $9.6^{\mathrm{a}, \mathrm{A}} \pm 0.57$ & $1044.04^{\mathrm{a}, \mathrm{A}} \pm 154.78$ \\
1 & $5.595^{\mathrm{b}, \mathrm{A}} \pm 0.03$ & $17.2^{\mathrm{b}, \mathrm{A}} \pm 0.56$ & $1021.13^{\mathrm{a}, \mathrm{A}} \pm 24.05$ & $5.535^{\mathrm{b}, \mathrm{A}} \pm 0.04$ & $17.6^{\mathrm{b}, \mathrm{A}} \pm 0.56$ & $1150.95^{\mathrm{a}, \mathrm{B}} \pm 7.40$ \\
2 & $5.125^{\mathrm{c}, \mathrm{A}} \pm 0.0$ & $25^{\mathrm{c}, \mathrm{A}} \pm 0.28$ & $1803.75^{\mathrm{b}, \mathrm{A}} \pm 106.71$ & $5.035^{\mathrm{c}, \mathrm{A}} \pm 0.01$ & $23^{\mathrm{c}, \mathrm{B}} \pm 0.28$ & $1988.27^{\mathrm{b}, \mathrm{A}} \pm 120.20$ \\
3 & $4.78^{\mathrm{d}, \mathrm{A}} \pm 0.0$ & $31.4^{\mathrm{d}, \mathrm{A}} \pm 0.28$ & $2341.45^{\mathrm{c}, \mathrm{A}} \pm 217.83$ & $4.765^{\mathrm{d}, \mathrm{A}} \pm 0.02$ & $30^{\mathrm{d}, \mathrm{A}} \pm 1.7$ & $3052.69^{\mathrm{c}, \mathrm{A}} \pm 219$ \\
3.5 & $4.65^{\mathrm{e}, \mathrm{A}} \pm 0.05$ & $32.6^{\mathrm{e}, \mathrm{A}} \pm 0.28$ & $4039.86^{\mathrm{d}, \mathrm{A}} \pm 385.99$ & $4.645^{\mathrm{e}, \mathrm{A}} \pm 0.02$ & $32.1^{\mathrm{d}, \mathrm{B}} \pm 0.28$ & $5370.45^{\mathrm{d}, \mathrm{A}} \pm 438.5$ \\
\hline
\end{tabular}

*Different superscript letters (a to e) within the same column and (A to $\mathrm{B}$ ) within same row showed significant differences among the groups ( $\mathrm{P}<0.05)$.

Table 5 The $\mathrm{pH}, \mathrm{SH}$ and viscosity values of the optimum mixtures of sheep-camel milk

\begin{tabular}{c|llllll}
\hline \multirow{2}{*}{$\begin{array}{c}\text { Time } \\
(\mathrm{h})\end{array}$} & \multicolumn{5}{|c}{$80: 20$} & \multicolumn{1}{c}{$70: 30$} \\
\cline { 2 - 7 } & \multicolumn{1}{c}{$\mathrm{pH}$} & \multicolumn{1}{c}{$\mathrm{SH}$} & \multicolumn{1}{c}{ Viscosity $(\mathrm{mPa} . \mathrm{s})$} & \multicolumn{1}{c}{$\mathrm{pH}$} & $\mathrm{SH}$ & Viscosity $(\mathrm{mPa} . \mathrm{s})$ \\
\hline 0 & $6.585^{\mathrm{a}, \mathrm{A}} \pm 0.007$ & $9.8^{\mathrm{a}, \mathrm{A}} 0.8$ & $1701.98^{\mathrm{a}, \mathrm{A}} \pm 46.87$ & $6.58^{\mathrm{a}, \mathrm{A}} \pm 0.02$ & $9.4^{\mathrm{a}, \mathrm{A}} \pm 0.28$ & $1886.60^{\mathrm{a}, \mathrm{A}} \pm 160.86$ \\
1 & $5.845^{\mathrm{b}, \mathrm{A}} \pm 0.0$ & $19.4^{\mathrm{b}, \mathrm{A}} \pm 0.28$ & $1609.55^{\mathrm{a}, \mathrm{A}} \pm 47.42$ & $5.895^{\mathrm{b}, \mathrm{B}} \pm 0.0$ & $17.4^{\mathrm{b}, \mathrm{B}} \pm 0.28$ & $1542.06^{\mathrm{a}, \mathrm{A}} \pm 48.02$ \\
2 & $5.35^{\mathrm{c}, \mathrm{A}} \pm 0.03$ & $25.4^{\mathrm{c}, \mathrm{A}} \pm 0.28$ & $1344.04^{\mathrm{a}, \mathrm{A}} \pm 26.31$ & $5.345^{\mathrm{c}, \mathrm{A}} \pm 0.0$ & $26.6^{\mathrm{c}, \mathrm{A}} \pm 0.28$ & $1527.30^{\mathrm{a}, \mathrm{B}} \pm 42.99$ \\
3 & $5.115^{\mathrm{d}, \mathrm{A}} \pm 0.0$ & $33^{\mathrm{d}, \mathrm{A}} \pm 0.28$ & $1396.67^{\mathrm{a}, \mathrm{A}} \pm 155.21$ & $5.055^{\mathrm{d}, \mathrm{A}} \pm 0.0$ & $33.6^{\mathrm{d}, \mathrm{A}} \pm 1.13$ & $1445.94^{\mathrm{a}, \mathrm{A}} \pm 156.5$ \\
4 & $4.915^{\mathrm{e}, \mathrm{A}} \pm 0.0$ & $37.8^{\mathrm{e}, \mathrm{A}} \pm 0.28$ & $5003.81^{\mathrm{b}, \mathrm{A}} \pm 930.17$ & $4.865^{\mathrm{e}, \mathrm{A}} \pm 0.04$ & $42^{\mathrm{e}, \mathrm{A}} \pm 0.56$ & $2097.54^{\mathrm{a}, \mathrm{A}} \pm 659.42$ \\
5 & $4.685^{\mathrm{f}, \mathrm{A}} \pm 0.0$ & $45.2^{\mathrm{f}, \mathrm{A}} \pm 0.56$ & $10857.06^{\mathrm{c}, \mathrm{A}} \pm 1170.36$ & $4.66^{\mathrm{f}, \mathrm{A}} \pm 0.0$ & $48.8^{\mathrm{f}, \mathrm{B}} \pm 0.56$ & $5584.76^{\mathrm{a}, \mathrm{B}} \pm 1555.5$ \\
\hline
\end{tabular}

Table 6 Water holding capacity (WHC) and syneresis values of the optimum values of mix of cow-goat-sheep and camel milk

\begin{tabular}{c|cccccccc}
\hline \multirow{2}{*}{ MT } & \multicolumn{2}{|c}{ 1.day } & \multicolumn{2}{c}{ 7.day } & \multicolumn{2}{c}{ 14.day } & \multicolumn{2}{c}{28. day } \\
\cline { 2 - 9 } & WHC & Syneresis & WHC & Syneresis & WHC & Syneresis & WHC & Syneresis \\
\hline T1 & $3.25 \pm 0.03$ & $14.45 \pm 6.52$ & $5.22 \pm 0.3$ & $9.22 \pm 0.5$ & $6.28 \pm 2.72$ & $9.13 \pm 2.32$ & $7.93 \pm 0.12$ & $10.95 \pm 1.45$ \\
T2 & $2.89 \pm 0.27$ & $13.96 \pm 3.32$ & $4.42 \pm 0.77$ & $8.66 \pm 2.91$ & $5.59 \pm 0.71$ & $11.10 \pm 0.21$ & $5.32 \pm 0.41$ & $14.24 \pm 0.0$ \\
T3 & $34.91 \pm 3.12$ & $15.71 \pm 4.39$ & $28.69 \pm 4.14$ & $18.76 \pm 3.72$ & $36.45 \pm 0.47$ & $25.68 \pm 2.83$ & $11.22 \pm 1.27$ & $35.14 \pm 3.31$ \\
T4 & $29.78 \pm 1.21$ & $30.68 \pm 3.18$ & $33.07 \pm 4.70$ & $26.89 \pm 3.5$ & $37.64 \pm 0.04$ & $28.09 \pm 0.004$ & $15.14 \pm 8.53$ & $27.05 \pm 1.86$ \\
T5 & $29.91 \pm 7.12$ & $12.36 \pm 0.27$ & $46.76 \pm 3.58$ & $22.14 \pm 7.61$ & $34.75 \pm 3.12$ & $34.85 \pm 4.22$ & $30.79 \pm 9.26$ & $49.93 \pm 9.68$ \\
T6 & $34.92 \pm 3.05$ & $12.59 \pm 3.26$ & $26.65 \pm 2.95$ & $11.56 \pm 0.13$ & $32.29 \pm 5.29$ & $16.27 \pm 4.80$ & $14.80 \pm 2.68$ & $25.49 \pm 3.17$ \\
\hline
\end{tabular}

MT: Milk type, T1: 80:20 cow-camel, T2: 70:30 cow-camel, T3: 80:20 goat-camel, T4: 70:30 goat-camel, T5: 80:20 sheep-camel, T6: 70:30 sheepcamel, ${ }^{*} \mathrm{WHC}$ and Syneresis values expressed as percentages (\%).

As a result of statistically analysis, there were no significant differences obtained for $\mathrm{pH}, \mathrm{SH}$ and viscosity values of 80\%:20\%goat-camel mixture and 70\%:30\% goat-camel mixture yoghurt samples during incubation $(\mathrm{P}>0.05)$. Additionally, there were significant change obtained for $\mathrm{pH}, \mathrm{SH}$ and viscosity values of $80 \%: 20 \%$ goatcamel mixture and 70\%:30\% goat-camel mixture yoghurt samples for 3.5 hour incubation $(\mathrm{P}<0.05)$.

In table 5 it was shown that the fermentation time was the longest in all milk combinations. Fermentation took 5 hours until $\mathrm{pH}$ falled to 4.7. After $5 \mathrm{~h}$ fermentation time the viscosity of $(10.857 \pm 1170 \mathrm{mPa} . \mathrm{s}) 80 \%: 20 \%$ sheep:camel milk mixture was higher than the viscosity of $(5584 \pm 1555$ mPa.s) 70:30 sheep:camel milk mixture. In this case this result was confirmed that the lower the concentration of camel milk in the mixture the higher the viscosity and the faster the $\mathrm{pH}$ drop for yoghurt production. One of the main reasons for this situation could be related with the chemical composition and chemical-physical properties of goat and sheep milk. During the incubation period of the mixture of goat:camel and sheep:camel milk it was observed a particle formation and this observation was higher the higher the ratio of camel milk in the mixture. This phenomenon is explained by Abu-Tarboush (1995) that proteolysis is higher in camel milk than in cow milk, which led to the particle formation in milk. It means that the proteolytic activity of Lactobacilli higher than streptococci and have the ability to hydrolyse casein.
As a result of statistically analysis, there were no significant differences obtained for $\mathrm{pH}, \mathrm{SH}$ and viscosity values of $80 \%: 20 \%$ sheep-camel mixture and 70\%:30\% sheep-camel mixture yoghurt samples at every hour $(\mathrm{P}>0.05)$. Moreover, there were significant differences obtained for $\mathrm{pH}, \mathrm{SH}$ and viscosity values of $80 \%: 20 \%$ sheep:camel mixture yoghurt sample and $\mathrm{pH}$ and $\mathrm{SH}$ values of 70\%:30\% sheep:camel mixture yoghurt sample for 5 hour incubation $(\mathrm{P}<0.05)$. There was no change observed for viscosity of 30 mixture yoghurt samples for 5 hour incubation $(\mathrm{P}>0.05)$.

As a result of this observations could be concluded that the high antimicrobial milieu of camel milk inhibits and supresses the growth of the starter culture and causes the splitting of casein fraction of the goat and sheep milk.

Similar to our study, Elniema and Tabiti (2015) investigated the influences of $75 \%$ camel milk $+25 \%$ cow milk, $50 \%$ camel milk $+50 \%$ cow milk, $25 \%$ camel milk $+75 \%$ cow milk and pure camel milk $(100 \%)$ on the chemical composition, $\mathrm{pH}$, acidity and sensory properties of yoghurt. They concluded that the best textural value was provided by yoghurt made from pure cow milk and high percentages of cow milk mixed with camel milk. El-Zubeir et al. (2012) also showed that the yoghurt made from camel milk had watery texture than the mixed camel and cow milk yoghurt, which were in agreement with our results.

During 1., 7., 14. and 28. days of storage, water holding capacity and syneresis analyses were also performed (Table 6). There was significance inverse correlation 
observed in syneresis and water holding capacity values in 1. day to 14. day of storage. The reason for irregular results on the 28th day may have an effect on the texture properties of the yoghurt samples.

\section{Conclusions}

Camel milk is consumed especially in the African countries without heating or without starter culture addition because of traditional habits. In addition, there were many researches showed that camel milk exhibits therapeutic properties and in this way it is used as a cure material against different kinds of diseases such as cancer, diabetes, autism, tuberculosis, asthma. Camel milk proteins have also functional properties. The aim of this work was to study was to combine the mentioned therapeutic and functional properties of camel milk to produce yoghurt for possible consumers' demand.

The optimum mixture was determined at 80\%:20\% cow:camel milk mixture.However, after 4 weeks of storage it was concluded that an increase in the syneresis and a decrease in water holding capacity $(\%)$ were found for yoghurt obtained from 80\%:20\%cow:camel milk mixture. The structure of yoghurt was very fragile and it could be broken easily.

This study indicated yoghurt production that made from mixture of camel and other (cow, goat, sheep milks) types of milks. The therapeutic effects of yoghurt obtained from mixtures should be investigated due to possibility of consumers' demands. Although through many investigations it was possible to get an increase in the viscosity with decreased proportions of camel milk, the produced yoghurt gels were not stabile during storage. Water holding capacity decreased while the syneresis of yoghurts increased.

Therefore, in future it is necessary to conduct more researches and to understand the mechanism and structure formation of yoghurt gels made from mixture of camel milk and other kinds of milk to visualise the gel network is used Scanning Electron Microscope (SEM) or other new techniques. To determine the stability of yoghurt gels the oscillation rheometer can be used due to its non destructive measurement principle.

\section{References}

Abdel Rahman IE, Dirar HA, Osman MA. 2009. Microbiological and biochemical changes and sensory evaluation of camel milk fermented by selected bacterial starter cultures. African Journal of Food Science, 3: 398-405

Abusheliabi A, Al-Holy MA, Al-Rumaithi H, Al-Khaldi S, AlNabulsi AA, Holley RA, Ayyas M. 2017. Growth Inhibition of Foodborne Pathogens in Camel Milk: Staphylococcus aureus, Listeria monocytogenes, Salmonella spp. and E. coli O157:H7. Czech Journal of Food Sciences, 35: 311-320

Abu-Tarboush HM. 1995. Comparison of Associative Growth and Proteolytic Activity of Yoghurt Starters in Whole Milk from Camels and Cows. Journal of Dairy Science, 79:366-371

Al-Ayadhi LY, Elamin E. 2013. Camel Milk as a Potential Therapy as an Antioxidant in Autism Spectrum Disorder (ASD), Evidence-based complementary and alternative medicine, ID 602834,8 pages

Al-Fakharany EM, Abu-Serie MM; Litus EA. 2018. The Use of Human, Bovine, and Camel Milk Albumins in Anticancer Complexes with Oleic Acid. Protein Journal, 37: 203-215
Ayyash M, Al-Nuaimi AK, Al-Mahadin S, Liu SQ. 2018. In vitro investigation of anticancer and ACE-inhibiting activity, aamylase and a-glucosidase inhibition, and antioxidant activity of camel milk fermented with camel milk probiotic: A comparative study with fermented bovine milk, Food Chemistry, 239: 588-592

Benkerroum N. 2008. Antimicrobial activity of lysozyme with special relevance to milk. African Journal of Biotechnology, 7: 4856-4867

Bornaz S, Sahli A, Attalah A, Attia H. 2009. Physico-chemical characteristics and renneting properties of camels' milk: A comparison with goats', ewes', and cows' milks. International Journal of Dairy Technology, 62: 505-513

Dario C, Carnicella D, Dario M, Bufano G. 2008. Genetic polymorphism of $\beta$-lactoglobulin gene and effect on milk composition in Leccese sheep. Small Ruminant Research, 74(1-3): 270-273.

Dean T. 1995. Cow's milk allergy: therapeutic options and immunological aspects. European journal of clinical nutrition, 49: 19-25.

Eissa EA, Yagoub AEA, Babiker EE, Ahmed, IAM. 2011. Physicochemical, Microbiological and Sensory Characteristics of Yoghurt Produced from Camel Milk During Storage. Electronic Journal of Enviromental, Agricultural and Food Chemistry, 10(6): 2305-2313

El Agamy EIM, Nawar S, Shamsia M, Awad S, Haenlein GFW. 2009. Are camel milk proteins convenient to the nutrition of cow milk allergic children. Small Rum. Res. 82: 1-6

El Zubeir IEM, Basher MAE, Alameen MH, Mohammed MAS, Shuiep ES. 2012. The Processing Properties, Chemical Characteristics and Acceptability of Yoghurt Made from Non Bovine Milks. Livestock Research for Rural Development 24 (3):

Elagamy SI, Ruppanner R, Ismail A, Champagne CP. 1992. Antibacterial and antiviral activity of camel milk protective proteins, Journal of Dairy Research, 59(2): 169-175

Elagamy EI, Ruppanne R, Ismail A, Champagne CP, Assaf R. 1996. Purification and Characterization of Lactoferrin, Lactoperoxidase, Lysozyme and Immunoglobulins from Camel's Milk. International Dairy Journal, 6: 129-145

Elniema AM, Tabiti MH. 2015. The effect of mixing different percentages of cow milk on the physiochemical characteristics of camel milk yoghurt and the sensory evaluation of yoghurt. World Journal of Pharmaceutical Sciences, 4 (9): 180-190

Farah Z, Atkins D, 1992. Heat coagulation of camel milk. Journal of Dairy Research, 59: 229-231.

Farah Z, Ruegg M. 1989. The size of distribution of casein micelles in camel milk. Food Microstructure 8: 211-216.

Gürsoy A. 2015. Sütün bileşimi ve özellikleri. Available from: https://www.foodelphi.com/sutun-bilesimi-ve-ozellikleriayse-gursoy/ [28 April 2019].

Hara K, Ikeda M, Saito S, Matsumoto S, Numata K, Kato N, Tan K, Sekihara H. 2002. Lactoferrin inhibits hepatitis B virus infection in cultured human, Hepatology Research, 24: 228-235

Hashim IB, Khalil AB, Habib H. 2009. Quality and acceptability of a set-type yoghurt made from camel milk. Journal of Dairy Science. Journal of Dairy Science 92: 857-862

Hassan RA, El-Zubeir IEM, Babiker SA. 2006. Microbiology of fermented camel milk (Gariss) in Sudan. Research Journal of Microbiology, Volume 1, pp 160- 165. Available at http://www.academicjournals.net/fulltext/jm/2006/160165.pdf.

Ibrahim AH, Khalifa SA. 2015. The effects of various stabilizers on physiochemical properties of camel milk yoghurt. Journal of American Science, 11(1): 15-24

Jans C, Bugnard J, Njage PMK, Lacroix C, Meile L. 2012. Lactic acid bacteria diversity of African raw and fermented camel milk products reveals a highly competitive, potentially health-threatening predominant microflora. LWT-Food Science and Technology, 47: 371-379 
Jenness R. 1980. Composition and characteristics of goat milk: review 1968- 1979. Journal of Dairy Science, 63(10): 16051630.

Jumah RY, Shaker R, Abu-Jdayil B. 2001. Effect of milk source on the rheological properties of yoghurt during the gelation process. International Journal of Dairy Technology, 54: 89-93

Kappeler S., 1998. Compositional and structural analysis of camel milk proteins with emphasis on protective proteins. Ph.D. Thesis, Swiss Federal Institute of Technology, Zurich,Switzerland, pp. 59-62

Kaskous S. 2016. Importance of camel milk for human health. Emirates Journal of Food and Agriculture, 158-163.

Konuspayeva G, Faye B, Loiseau G, Levieux D. 2007. Lactoferrin and immunoglobulin contents in camel's milk (Camelus bactrianus, Camelus dromedarius, and Hybrids) from Kazakhstan. Journal of Dairy Science, 90(1): 38-46.

Kumar D, Kumar CM, Singh R, Mehta N, Kumar P. 2016. Antioxidant and antimicrobial activity of camel milk caseinhydrolysates and its fractions. Small Ruminant Research, 139: 20-25

Kurt A, Çakmakçi S, Çaglar A. 1993. Süt ve Mamülleri Muayene ve Analiz Metodlari Rehberi; Erzurum, Turkiye

Motrich RD, Gottero C, Rezzonico Jr C, Rezzonico C, Riera CM, Rivero V. 2003. Cow's milk stimulated lymphocyte proliferation and TNF $\alpha$ secretion in hypersensitivity to cow's milk protein. Clinical Immunology, 109(2): 203-211.

Mudgil P, Kamal H, Yuen GC, Maqsood S. 2018. Characterization and identification of novel antidiabetic and anti-obesity peptides from camel milk protein hydrolysates. Food Chemistry, 259: 46-54
Park YW, Juárez M, Ramos M, Haenlein GFW. 2007. Physicochemical characteristics of goat and sheep milk. Small ruminant research, 68(1-2): 88-113.

Sahan N, Yasar K, Hayaloglu AA. 2008. Physical, chemical and flavour quality of non-fat yoghurt as affected by a $\beta$-glucan hydrocolloidal composite during storage. Food Hydrocolloids, 22(7): 1291-1297.

Selvaggi M, Laudadio V, Dario C, Tufarelli V. 2014. Investigating the genetic polymorphism of sheep milk proteins: a useful tool for dairy production. Journal of the Science of Food and Agriculture, 94(15): 3090-3099.

Semen Zeynep, Altintas A. 2016. Biological and Therapeutic Effects of Dietary Camel Milk. Journal of Turkish Veterinary Medical Association. 15: 85-101.

Shimaa AI, Ibtisam EM El Zubeir. 2016. Processing, composition and sensory characteristic of yoghurt made from camel milk and camel-sheep milk mixtures. Small Ruminant Research, 136: $109-112$

Shirai K, Guerrero I, Huerta S, Saucedo G, Castillo A, Gonzalez RO, Hall GM. 2001. Effect of initial glucose concentration and inoculation level of lactic acid bacteria in shrimp waste ensilation. Enzyme and Microbial Technology, 28(4-5): 446452.

Tamime AY, Barrantes E, Sword AM. 1996. The effect of starch based fat substitutes on the microstructure of set style yoghurt made from reconstituted skimmed milk powder. Journal of the Society of Dairy Technology, 49(1): 1-10.

Yagil R. 1982. Camels and camel milk. FAO. 